\title{
PYOGENIC GRANULOMAS OF THE LACRIMAL SAC
}

\author{
MARY N. ASIYO and FRITZ H. STEFANI \\ Kenya and Germany
}

\begin{abstract}
SUMMARY
Eight cases of pyogenic granulomas of the lacrimal sac are reported. The clinical symptoms were consistent with chronic dacryocystitis which was unresponsive to previous probing and antibiotics. Extirpation of the sacs was done because of dacryocystocoele, pyocoele, or fistula formation through the skin. Trauma and inflammation were thought to have contributed to the growth of the pyogenic granulomas. The histopathological examination revealed nonspecific granulomas consisting of well vascularised, friable tissue of a myxomatous nature containing an infiltration of lymphocytes, plasma cells, and a few eosinophils. Over the granulomas an epithelial layer of cells is stretched showing no signs of dysplasia or neoplastic growth. The term 'lobular capillary hemangioma' has been suggested to describe lesions morphologically similar to those observed in the study. These masses made up 53.3\% of a total of 15 lacrimal sac tumour biopsy specimens examined over a period of 10 years (19791989). The few reported cases of primary lacrimal sac tumour of non-epithelial origin suggest that they make up a large minority of the lacrimal sac tumours. A review shows that relatively few of these lesions have been described in recent English literature but these growths are probably not being as consistently reported as primary epithelial tumours.
\end{abstract}

Pyogenic granulomas arise at any age in either sex as primary vascular lesions of the skin and mucosal membranes with a predilection for the head and neck. Usually the lesion develops rapidly within a few weeks or months. Macroscopically it may present as a pedunculated polypoid red nodule. Inflammation is regarded as a secondary reaction in the later course. Histologically there are numerous capillaries and small blood vessels budding from central feeding vessels within an oedematous connective tissue core.

Although common in the conjunctiva, pyogenic granuloma has hardly ever been described within the lacrimal

From Kenyatta National Hospital, PO Box 14937, Nairobi, Kenya and Department of Ocular Pathology, University of Munich Eye Hospital.

Correspondence to: Professor F. H. Stefani MD, Department of Ocular Pathology, University of Munich Eye Hospital, Mathildenstr 8, 8000 Munich 2, Germany. drainage system where it may cause obstruction, inflammation and thus symptoms such as epiphora. In the skin this mass is regarded as a primary vascular process in the sense of an acquired capillary hemangioma, and it is differentiated from true granulation tissue following preceeding inflammatory tissue damage. Granulation tissue is a reactive reparative tissue following tissue damage such as inflammation. It must also be distinguished from an angiosarooma and Kaposi sarcoma.

The aetiology of pyogenic granulomas usually remains obscure. Sometimes pregnancy may be a factor, inflammation is regarded as a secondary reaction in the later course. In contrast to the generally accepted view pyogenic granulomas in the lacrimal drainage system commonly seem to arise as a reaction to chronic inflammation in adjacent tissues.

Chronic inflammation in the outer wall of the lacrimal drainage system may induce localised damage of the overlying epithelial basement membrane. This allows local fibrovascular ingrowth under the affected mucous membrane giving rise to a nodular polypoid mass with oedematous connective tissue and ectatic blood vessels, the features of a granuloma pyogenicum telangiectaticum, which is unlike resorptive reactive granulation tissue. Initially the overlying epithelial cells in the lacrimal drainage system often show additional reactive changes such as mucous secretion.

Circumscribed pyogenic granulomas comprise the commonest type of growth in the lacrimal $\mathrm{sac}^{1}$, but because lacrimal sac tumours are rare $^{2}$ an impression that inflammatory tumours are also rare may be created. A literature review shows that few of these lesions have been reported. In our experience, these tumours occur more frequently among lacrimal sac tumours than has been reported. The histopathological appearance and frequency of occurrence of pyogenic granulomas among the surgical biopsy specimens of a series of patients with a clinical diagnosis of chronic dacryocystitis or lacrimal sac tumour is presented.

\section{MATERIALS}

Eight surgical biopsy specimens out of 15 lacrimal sac tumours seen by the ocular pathology department of the 
Table I. Clinical date on 8 cases of pyogenic granuloma of the lacrimal sac

\begin{tabular}{|c|c|c|c|c|c|c|}
\hline $\begin{array}{l}\text { Case } \\
\text { No. }\end{array}$ & $\begin{array}{l}\text { Path } \\
\text { No. }\end{array}$ & Sex & $\begin{array}{l}\text { Age in } \\
\text { years }\end{array}$ & $\begin{array}{l}\text { Onset of } \\
\text { symptoms }\end{array}$ & $\begin{array}{l}\text { Duration of } \\
\text { symptoms }\end{array}$ & $\begin{array}{l}\text { Clinical } \\
\text { diagnosis }\end{array}$ \\
\hline 1 & M37/79 & $\mathrm{F}$ & 70 & insidious & chronic 1 year & $\begin{array}{l}\text { chronic dacryocystitis } \\
\text { with dacryocystocoele }\end{array}$ \\
\hline 2 & M724/88 & $\mathrm{F}$ & 72 & insidious & recurrent 20 years & $\begin{array}{l}\text { chronic dacryocystitis } \\
\text { with dacryocystocoele }\end{array}$ \\
\hline 3 & M145/80 & $\mathrm{F}$ & 70 & insidious & chronic 3 years & $\begin{array}{l}\text { chronic dacryocystitis } \\
\text { with pyocoele }\end{array}$ \\
\hline 4 & M597/88 & $\mathrm{F}$ & 47 & insidious & recurrent 2 years & $\begin{array}{l}\text { chronic dacryocystitis } \\
\text { with pyocoele }\end{array}$ \\
\hline 5 & M146/89 & $\mathrm{F}$ & 52 & insidious & chronic over 2 years & $\begin{array}{l}\text { chronic dacryocystitis } \\
\text { with dacryocystocoele }\end{array}$ \\
\hline 6 & M386/86 & $\mathbf{M}$ & 41 & abrupt & recurrent 2 years & $\begin{array}{l}\text { chronic dacryocystitis } \\
\text { with dacryocystocoele }\end{array}$ \\
\hline 7 & M137/88 & $\mathrm{F}$ & 73 & insidious & chronic 5 years & $\begin{array}{l}\text { chronic dacryocystitis } \\
\text { with fisula (skin) }\end{array}$ \\
\hline 8 & M763/85 & $\mathbf{M}$ & 50 & insidious & chronic 4 years & $\begin{array}{l}\text { chronic dacryocystitis } \\
\text { lid abscess malignancy }\end{array}$ \\
\hline
\end{tabular}

University of Munich Eye Hospital in a 10 year period (1979-1989) are the basis for this report. A short summary of the clinical data of the patients is given and the total number of lacrimal sac surgical biopsy specimens seen during this period is specified with respect to their histopathological diagnoses.

\section{Clinical Findings}

The clinical findings are summarised in Table I. The median age for all patients with lacrimal sac granulomas was 68 years. There was an increased female to male ratio (six females and two males). Onset of symptoms was insidious in all cases except case no. 4, where it was abrupt. The duration of the symptoms of chronic dacryocystitis was between one to 20 years (mean five years). All patients had been unresponsive to previous probing and antibiotic therapy. None had a history of serosanguinous

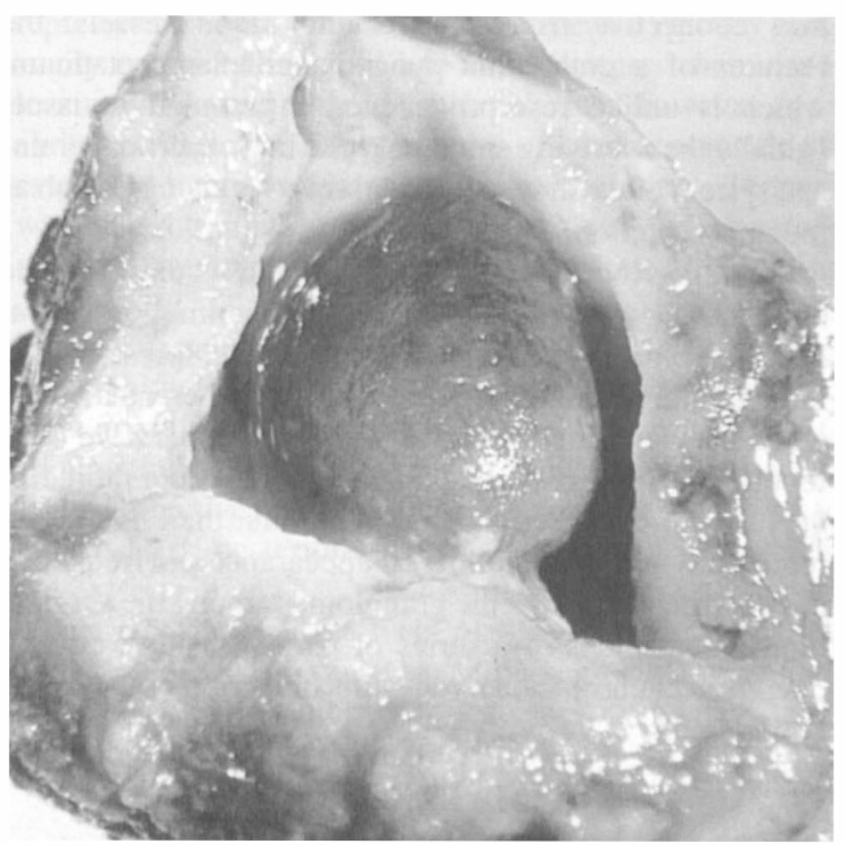

Fig. 1. (case no. 1) Fresh surgical specimen of a lacrimal sac polypoid tumour. Published by Stefani FH, Gabel V-P. Wasserstein $D B$ [22]. or sanguinous discharge (even during atraumatic irrigation). Four cases were extirpated for dacryocystocoele, two for pyocoele, one for fistula formation through the skin, and one due to a lower lid abscess and suspicion of malignancy.

\section{Common Features}

There was no history of serosanguinous or bloody discharge. No specific infectious invasive micro-organisms were detected on histologic examination and the more frequently cultured organism was staphylococcus aureus.

\section{Pathologic Findings}

A fresh surgical specimen of a polypoid tumour is illustrated in Figure 1. The light microscopic appearance of it and others are illustrated in Figures 2-6.

On gross examination the tumours appear as round masses, sometimes mushroom-polypoid (Figure 1). The tumours are dark red showing moderate to marked vascularity on the cut surface (Figure 3 ). They are firmly attached to the thickened walls of the lacrimal sac by stalks of varying sizes (Figure 4).

Microscopic examination reveals tumours composed of

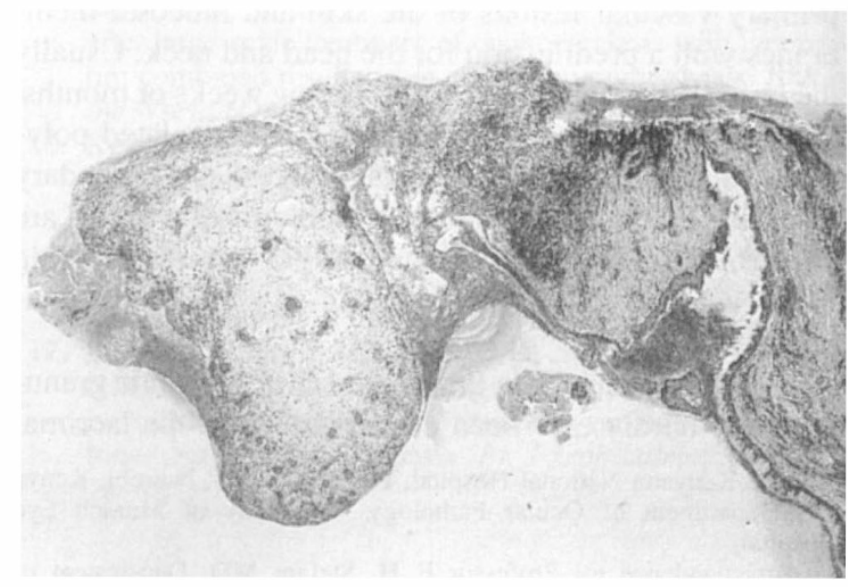

Fig. 2 (case no. 1) Chronic dacryocystitis with pyogenic granuloma of lacrimal sac. Haematoxylin-eosin, original magnification $25 \times$. 


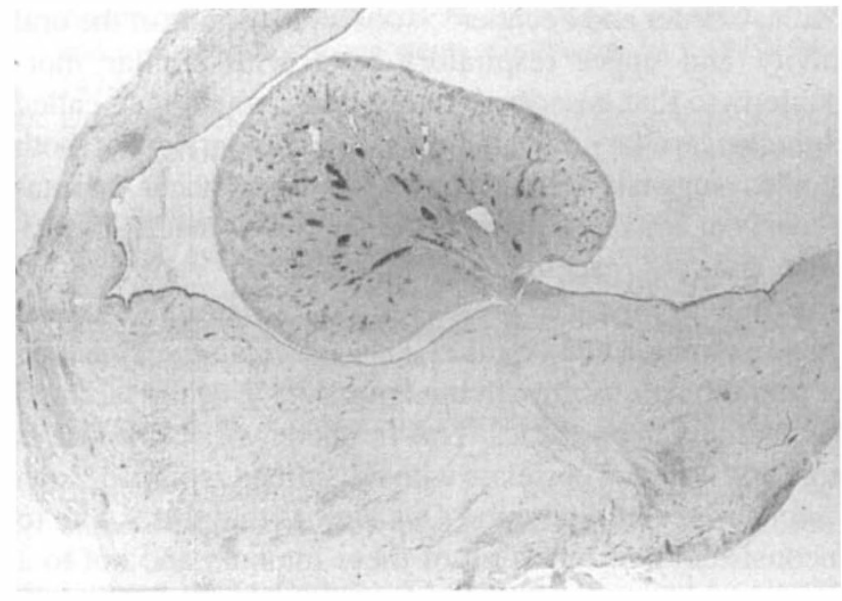

Fig. 3 (case no. 7) Chronic dacryocystitis with pyogenic granuloma of the lacrimal sac showing marked oedema. Haematoxylin-eosin, original mangification $25 \times$.

an oedematous connective tissue which is densly infiltrated by inflammatory cells. The inflammatory cells consist mainly of lymphocytes, plasma cells, and a few oesinophils. As expected they exhibit a well developed vascular component (Figure 5). The surface of the tumours is covered by a loose layer of flattened, periodically discontinuous epithelial cells with no dysplasia or neoplasia. The scarred walls of the lacrimal sacs are infiltrated by chronic inflammatory cells with some leucocytes interspersed in the tissue, while the epithelial lining shows mainly leucocytic infiltration (Figure 6).

\section{DISCUSSION}

The cases reported here show that a lacrimal passage obstructive disease manifesting as chronic dacryocystitis is frequently accompanied by a pyogenic granuloma. It is documented that similar masses have appeared either without a preceding history ${ }^{3}$, following injury from a wound $^{4}$ or after probing ${ }^{5,6}$. There are also reports of granulomas occurring as a reaction to a retained foreign body such as hair ${ }^{7}$, a plastic tube ${ }^{8}$, or silicone tubing ${ }^{9,10,11}$. In our

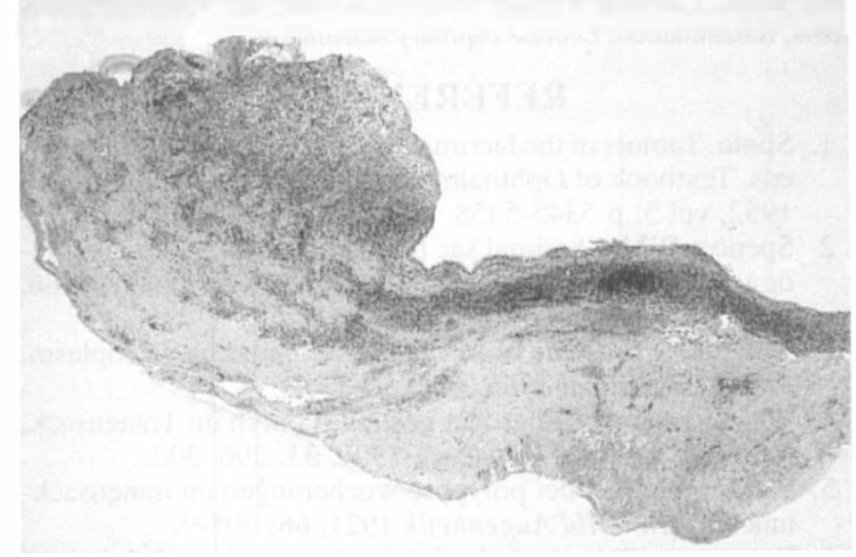

Fig. 5 (case no. 4) The granulomas consist of chronic inflammatory cell infiltrate. Lymphocytes, occasional plasma cells and a few eosinophils are seen in the oedematous well vascularised tissue of the pyogenic granulomas. Haematoxylineosin, original magnification $60 \times$.

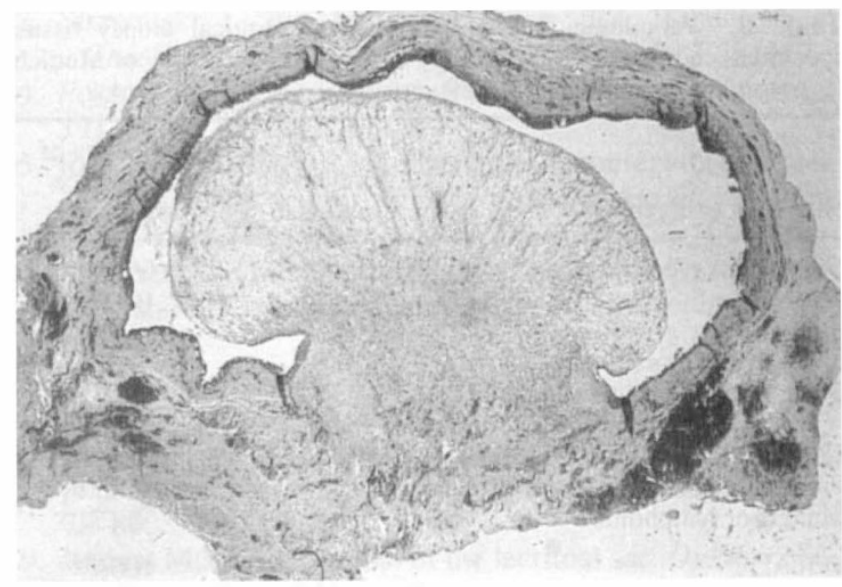

Fig. 4. (case no. 4) Chronic dacryocystitis with pyogenic granuloma of the lacrimal sac. Haematoxylin-eosin, original magnification $25 \times$. The tumour is attached to the lacrimal sac wall by a broad short stalk.

study, there was a history of probing several weeks prior to extirpation or earlier in the course of the disease, and in one case fistula formation may have induced the growth of these lesions, as may spontaneous rupture of the $\mathrm{sac}^{12}$. The male to female ratio of the occurrence of pyogenic granulomas was 1:3 and most reported published granulomas of the lacrimal sac are in women. More female than male patients experience epiphora, typically after the age of 40 , and subsequently develop signs and symptoms of chronic or acute dacryocystitis ${ }^{13,14}$. There is no proven explanation for the increased prevalence in women ${ }^{15}$. Histopathological examination failed to reveal evidence of any invasive infection, and micro-organism were not identified in the biopsy specimens. The concept of traumatic origin alone was doubted as early as $1891^{16}$. This overgrowth of granulation tissue appears to occur on the basis of inflammation and trauma.

Clinically there was an insidious onset of symptoms in the majority of cases, over a period of one year or more. The tumours presented as erythematous, periodically tender, compressible masses with no serosanguinous or

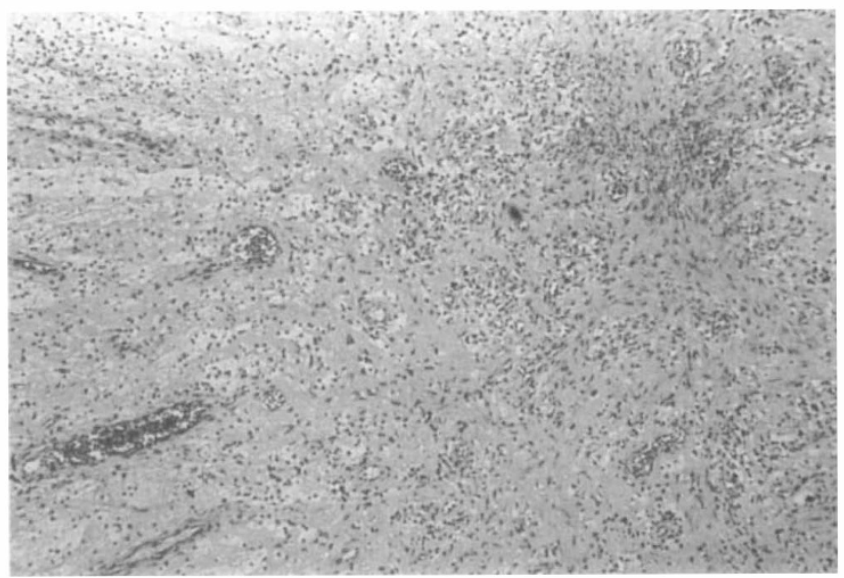

Fig. 6. (case no. 8) Chronic dacryocystitis with pyogenic granuloma of the lacrimal sac. The scarred and thickened wall of the lacrimal sac is infiltrated by inflammatory cells. Haematoxylin-eosin, original magnification $25 x$. 
Table II. Pathologic data of lacrimal sac surgical biopsy tissue specimens seen by ocular pathology department University of Munich Eye Hospital between 1979-1989

\begin{tabular}{lcc}
\hline Histological diagnosis & $\begin{array}{c}\text { Number of } \\
\text { patients }\end{array}$ & $\begin{array}{c}\text { Frequency of } \\
\text { occurrence } \\
\text { in per cent }\end{array}$ \\
\hline Chronic dacryocystitis & 60 & $66.7 \%$ \\
$\begin{array}{l}\text { Dacryoliths } \\
\text { Inflammatory granuloma }\end{array}$ & 9 & $10.0 \%$ \\
$\quad$ (pyogenic granuloma) & 8 & $8.9 \%$ \\
$\quad \begin{array}{l}\text { Scarring and fibrogranulomatous } \\
\text { reaction }\end{array}$ & 6 & $6.7 \%$ \\
$\begin{array}{l}\text { Parcinomas } \\
\text { Pseudotumour }\end{array}$ & 5 & $5.5 \%$ \\
Malignant lymphoma & 1 & $1.1 \%$ \\
TOTAL & 1 & $1.1 \%$ \\
\hline
\end{tabular}

Table III. Pathologic data of lacrimal sac tumour tissue received between 1979-1989

\begin{tabular}{lcr}
\hline Histological diagnosis & $\begin{array}{c}\text { Number of } \\
\text { patients }\end{array}$ & $\begin{array}{c}\text { Per cent } \\
\text { represented }\end{array}$ \\
\hline $\begin{array}{l}\text { Inflammatory granuloma } \\
\quad \text { pyogenic granuloma) }\end{array}$ & 8 & $53.3 \%$ \\
Pseudotumour & 1 & $6.7 \%$ \\
Malignant lymphoma & 1 & $6.7 \%$ \\
Squamous cell carcinoma & 3 & $20.0 \%$ \\
Transitional cell carcinoma & 1 & $6.7 \%$ \\
Metastatic carcinoma & 1 & $6.7 \%$ \\
TOTAL & 15 & $100 \%$ \\
Benign tumours & & $60.0 \%$ \\
Malignant (primary) & & $40.0 \%$ \\
\hline
\end{tabular}

bloody discharge, with associated lacrimal sac complications of dacryocystocoele, pyocoele or fistula formation. It is known that lacrimal sac tumours may mimic chronic dacryocystitis ${ }^{17,18}$ and the confined position of the lacrimal sac behind the anterior lacrimal crest and several soft tissue layers is known to make the clinical diagnosis of tumours in this area difficult ${ }^{19}$. As in the case of most dacryoliths ${ }^{20}$, the granulomatous masses were only diagnosed when they were encountered at the time of surgery, or they were recognised after biopsy.

This series of granulomas of the lacrimal sac is very similar to those reported in the literature ${ }^{16.21-29}$. Isolated case reports or small series of cases of tumours of the lacrimal sac have been reported since $1973^{2}$. Reports of such granulomas are rare among them. Most cases published are described as polyps or pseudopolyps. The pyogenic granulomas of the lacrimal sac have been characterised by their friable tissue usually of a myxomatous nature infilrated by lymphocytes and plasma cells over which an epithelial layer without signs of neoplastic growth may be stretched. Occasionally vascularity may be the outstanding feature ${ }^{5.4 .26}$ (telangiectatic granuloma) and in other cases the cellular content, particularly of the plasma cells, may be so great that the term plasmoma or plasma cell granuloma has been applied ${ }^{29-33}$. The pyogenic granulomas reported by us are characterised by their polypoid growth pattern into the lacrimal sac lumen. Some inflammatory infiltrates with a prominent vascular network and a friable, oedematous connective tissue are typical features.
Mills, Cooper and Fechner ${ }^{33,35}$ observed lesions of the oral cavity and upper respiratory tract with similar morphology to that described in this study, which they called 'lobular capillary hemangioma'. A comparison of both studies suggests that such lesions may occur spontaneously or as a reactive process. Our view is that telangiectatic and plasmacellular granulomas are variations of inflammatory induced granulomas of the lacrimal sac like those examined and reported by us in this study. This type of granulomatous growth made up $53.3 \%$ of the lacrimal sac tumours in our series. This frequency of occurrence is high and does not correlate with the limited reports of such lesions in recent literature. Our view is that this is due to inconsistency of reporting of these tumours and not to a diminished frequency.

\section{CONCLUSIONS}

Lacrimal drainage system obstruction is a common ophthalmic problem comprising up to $3 \%$ of clinic visits in some studies ${ }^{13,14}$. The frequency of polypoid formation in chronic dacryocystitis has been differently estimated from $33 \%$ of 100 cases $^{26}$, to one in 162 cases $^{1}$. We found $8.9 \%$ of 90 cases of surgical biopsy specimens of extirpated sacs had pyogenic granulomas (Table II). These growths comprised $53.3 \%$ of all lacrimal sac tumours (Table III). Stefani $^{12}$ expressed the view that the limited number of published cases of these lesions may possibly not reflect the incidence of these granulomatous growths. An informal survey done by the Wills Eye Hospital oculoplastic staff concerning lacrimal sac masses treated within a five year period (1982-1986) showed that granuloma was a common diagnosis $(36 \%$ of the lacrimal sac masses excluding dacryoliths $)^{36}$. Flanagan and Stokes suggest that benign tumours of the lacrimal sac are not being reported as consistently as malignancies ${ }^{36}$. The results presented here reflect a relatively high number of granulomas among lacrimal sac masses. We think that inflammatory tumours of the lacrimal sac occur more frequently than is reflected in the literature.

Key words: Lacrimal drainage system, Lacrimal sac, Pyogenic granuloma, Inflammation, Lobular capillary hemangioma.

\section{REFERENCES}

1. Spoto. Tumors of the lacrimal passages. In: Duke-Elder SW, eds. Textbook of Ophthalmology. St Louis: CV Mosby Co, 1952, vol 5: p 5345-5358.

2. Spencer WM. Lacrimal sac tumors. In: Ophthalmic pathology. An atlas and textbook. WB Saunders Company, 1986, vol 3: p 2313-2336.

3. Nolan J. Granuloma of lacrimal sac simulating a neoplasm. Am J Ophthalmol 1966, 62: 756-7.

4. Wagenmann A. Ein großer gestielter Polyp im Tränensack. Ber Ophthal Ges Heidelberg 1906, 33: 296-302.

5. Piesbergen M. Über polypöse wucherungen im tranensackinneren. Klin Mbl Augenheilk 1921, 66: 695-9.

6. Bouzas A. Polyps of the lacrimal sac. Arch Ophthalmol 1961, 66: 236-40.

7. Stallard HB. A case of chronic granuloma of the lacrimal sac. Br J Ophthalmol 1940, 24: 457-9.

8. Weizenblatt S. Primary calculus of the lacrimal sac. Arch Ophthalmol 1952, 48: 61-5. 
9. Anderson RL and Edwards JJ. Inductions, complications and results with silicone stents. Ophthalmology 1979, 94: 1474-87.

10. Dortzbach RK, France TD, Kishner BJ, Gonnering RS. Silicone intubation for obstruction of nasolacrimal duct in children. Am J Ophthalmol 1982, 94: 585-90.

11. Dresner SC, Codere F, Brownstein S, Jouve P. Lacrimal drainage system inflammatory masses from retained silicone tubing. Am J Ophthalmol 1984, 98: 609-13.

12. Stefani FH. Polypoid mass of the lacrimal sac. Presented at the European Opththalmic Pathology Society Meeting, 1979.

13. Traquair HM. Chronic dacryocystitis, its causation and treatment. Arch Ophthalmol 1941, 26: 165-80.

14. Scott GI, Summerskill WH. Discussion on treatment of chronic dacryocystitis. Trans Ophthalmol Soc UK 1949, 69: 477-505.

15. Linberg JV, McCormick SA. Primary acquired nasolacrimal duct obstruction. A clinicopathological report and biopsy technique. Ophthalmology 1986, 93: 1055-62.

16. Berlin. In: Discussion of Kuhnt' paper. Versg Ophthalmol Ges Heidelberg 1891; 20: 245.

17. Ryan SJ and Font RL. Primary epithelial neoplasms of the lacrimal sac. Am J Ophthalmol 1973, 76: 73-88.

18. Hornblass A, Jakobiec FA, Bosnak S, Flanagan JC. The diagnosis and management of epithelial tumors of the lacrimal sac. Ophthalmology 1980, 87: 476-89.

19. Stefani FH, Gavel V-P, Wassestein D, Brandt F. Unerwarete Befunde bei Operationen an den abfuhrenden Tränenwegen. Ber Dtsch Ophthalmol Ges 1980, 77: 169-74.

20. Veirs RA. Tumors of the lacrimal sac. In: Textbook on lacrimal disorders. Diagnosis and treatment. CV Mosby Co, 1976; p 83-86.

21. von Graefe A. Polypen des Tränenschlauches. v Graefes Arch Ophthalmol 1854, 1: 283-8.

22. Hertel E. Beitrag zur pathologischen anatomie der tranensackerkrankungen. v Graefes Arch Ophthalmol 1899, 48: 21-57.
23. Strzemiski I. Ein Fall von Polyp des Tranensackes. v Graefes Arch Ophthalmol 1900, 49: 339-47.

24. Pokrowsky AJ. Sur les polypes du sac lacrimal. Ann Oculist 1912, 147: 369-75.

25. Rollet I and Bussy L. Recherches anatomopathologiques sur cent cas de dacryocystitis avec extraction du sac et du canal. Arch d'Ophthalmol 1923; Paris, 40: 321-43.

26. Scheerer R. Granuloma tellangiektodes der Karunkelgegend und des Tränensackinnern. Klin Mbl Augenheilk 1931, 86: 445-9.

27. Brand I. Beitrag zur symptomatologie und operation des tranensackpolypen. Klin Mbl Augenheilk 1951, 118: 172-5.

28. Radnat $\mathbf{M}$ and Renemar L. Beitrag zur diagnostik der sog pralakrimalen Tumoren. Klin Mbl Augenheilk 1951, 118: 78-80.

29. Radnat M, Gall J. Tumors of the lacrimal sac. Ophthalmolgic, Basel, 1966, 151: 1-22.

30. Verhoeff FM and Derby GS. Plasmoma of the lacrimal sac. Arch Ophthalmol 1915, 44: 252-64.

31. Cardello G. Sul plasmoma del sacco lacrimale. Rass Ital Ottalmol 1936, 5: 238-57.

32. Toselk C. Plasmoma del sacco lacrimale. Rass Ital Ottalmol 1949, 18: 333-9.

33. Heathcote JG, Allen LH, Willis NR. Plasma cell granuloma of the lacrimal sac. Can J Opthalmol 1987, 22: 387-90.

34. Fechner RE, Cooper PH, Mills SE. Pyogenic granuloma of the larynx and trachea. A causal and pathologic misnomer for granuloma tissue. Arch Otolaryngol 1981, 107: 30-2.

35. Mills SE, Cooper PH, Fechner RE. Lobular capillary hemangioma: the underlying lesion of pyogenic granuloma. A study of 73 cases from the oral and nasal mucous membranes. Am J Surg Pathol 1980, 4: 470-9.

36. Flanagan JC, Zolli CL. Lacrimal sac tumors: surgical management. In: Lenberg JV ed. Contemporary issues in ophthalmology. New York: Church Livingstone Inc 1988, 5: 203-225. 